$$
\begin{gathered}
S \beta 321 \\
L 75
\end{gathered}
$$




$$
-75
$$




\title{
UNIVERSITY OF ILLINOIS BULLETIN
} ISSUED WEEKLY

V'ol. XV

FEBRUARY 18, 1918

No. 25

[Entered as second-class matter December I1, 1912, at the post office at Urbana, Illinois, under the Act of August 24, 1912.]

\section{THE WAR GARDEN}

\author{
By \\ J. W. L L O Y D \\ Professor of Olericulture
}

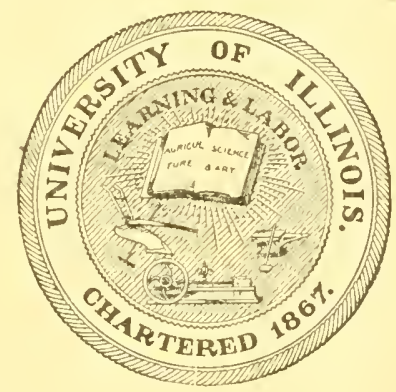

\section{PUBLISHED BY THE UNIVERSITY OF ILLINOIS}

Under the Direction of the War Cominttee

URBANA

"The proportion of our national diet in vegetables is very low, and it will not only do no harm to increase it, but in fact will contribute to public health."-Herbert Hoover. 


\section{OBJECTS OF THE WAR GARDEN}

I. To enable the fanily to produce a supply of vegetables which may be substituted in part for cereals and meats.

2. To grow food supplies at home and thus relieve transportation facilities.

Our Army and our Allies need the concentrated foods that can readily be transported; and the transportation facilities are needed to carry war supplies. The free use of home-grown vegetables will aid materially in both these matters.

\section{WHAT TO PLANT IN A WAR GARDEN}

I. Vegctables of high food zalue. (a) Vegetables rich in protein (meat-savers): Dry beans, fresh Lima beans, green peas. (b) Vegetables rich in carbohydrates (substitutes for other foods rich in starch or sugar): Potatoes, beans, sweet corn, peas, parsnips, beets, carrots, onions.

2. Vegctables suitable for camming: Sweet corn, tomatoes, string beans, peas-staple canned goods of the market; easily produced at home. If cans are scarce the corn may be dried.

3. Vegetables that may bc stored fresh: Potatoes, beets, carrots, parsnips, onions. Production and storage at home save transportation.

4. Vegetables for summer use: In addition to the sorts mentioned above, plant lettuce, spinach, turnips, and early cabbage. Confine your efforts to staple products; do not experiment with vegetables difficult to grow in your locality.

\section{HOW MUCH TO PLANT}

For the winter supply, plant enough to have one quart of canned vegetables to five persons every day, for seven months. This would mean approximately 2 IO quarts. In addition to the canned vegetables, those stored for winter use should include, for a family of five, approximately fifteen bushels of potatoes, five bushels of root crops (parsnips, carrots, beets), and three bushels of onions. A halfbushel of dry beans should also be grown if the locality is well adapted to this crop and facilities for threshing are available.

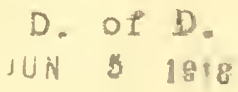


The following table gives the amounts of seed and land required, under normal Illinois conditions and good care, to produce the quantities of food materials mentioned above.

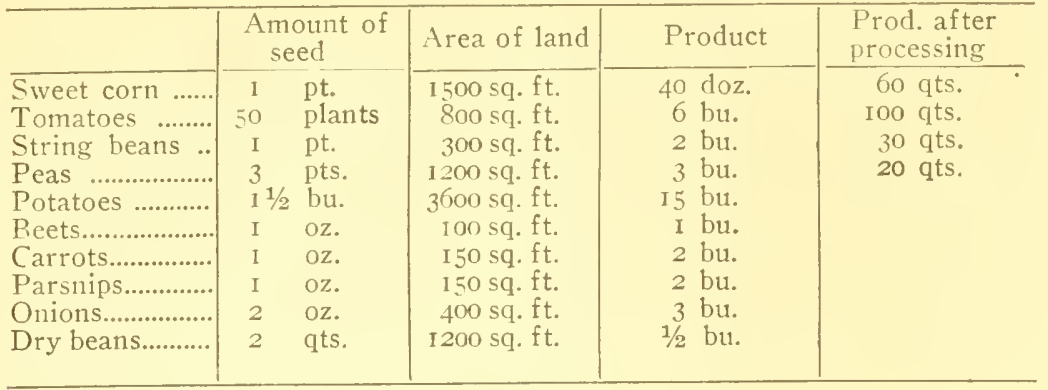

Lima beans may be advantageously substituted for part of the corn. The total area of land indicated is 9,400 square feet-equivalent to a town lot 66 by approximately I 42 feet. For growing a supply of vegetables for summer $11 \mathrm{se}$, about 50 percent additional seed and space would be required.

\section{WHAT TO DO AND HOW}

I. Prepare the soil thoroughly before planting. If manure can be obtained, apply it before plowing. Plow as early as the soil is in suitable condition for working. Disk and harrow until the surface is thoroughly pulverized. Use steamed bone meal and dried blood for fertilizer if manure cannot be obtained. Mix these materials with the surface soil by harrowing. Finish the preparation of the seed bed for small seeds by planking or hand-raking.

2. Plant good secd. Seed is scarce this year; order early.

3. Plant carcfully. Don't waste any seed. Plant small seeds shallow and large seeds more deeply. Firm the soil well over the seeds after covering.

4. Plant at the proper distances. Allow enongh space between rows for tillage and for full development of the plants. Corn needs more space than carrots.

5. Plant at the right time. Potatoes, peas, beets, carrots, parsnips, and onions should be planted early - as early as the ground can be worked in spring. The planting of beans, corn, and tomatoes must be deferred until the weather is warm. 
6. Take good care of the growing crops. Cultivate srequentiy. Weed and thin where necessary. Protect from attacks of insects and fungous diseases.

\section{GET MORE INFORMATION}

Get Circular No. Ig8, on Home Vegetalle Gardening, from the Illinois Igricultural Experiment Station, Urbana, Illinois; and the following publications from the United States Department of Agriculture, Washington. D. C.: Farmers' Bulletin 8ı, The Snall Vegetable Garden; Farmers' Bulletin 853, Home Canning of Fruits and Vegetables; Farmers' Bulletin 879, Home Storage of Vegetables.

\section{IVHAT TO DO NOW}

I. Select your garden site.

2. Plan your garden.

3. Order your seeds.

4. Read gardening literature. 


$$
L 75
$$




\section{LIBRARY OF CONGRESS}

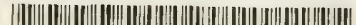

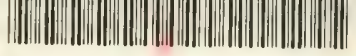

00009284941 